\title{
KARST SPRING CUTOFFS, CAVE TIERS, AND SINKING STREAM BASINS CORRELATED TO FLUVIAL BASE LEVEL DECLINE IN SOUTH-CENTRAL INDIANA
}

\author{
Garre A. Conner \\ Pangea Geoservices, 2911 Mesker Park Drive,Evansville, Indiana, 47720,USA, GConner@alumni.iu.edu
}

\begin{abstract}
The Mitchell Aquifer averages $80 \mathrm{~m}$ in thickness and underdrains a karst region in the Crawford Upland and Mitchell Plateau region in south-central Indiana $\left(110,000 \mathrm{~km}^{2}\right)$. The Springville Escarpment is a transitional boundary between the upland and plateau. Cave stream linking between cave tiers in the aquifer and correlation of cave tier inception horizons to a base level decline surface is interpreted for the Kirby Watershed, encompassing the prekarst headland of Indian Creek $\left(42 \mathrm{~km}^{2}\right)$. The watershed was severed from lower Indian Creek at Eller Col by limestone cavern drainage on the ridge between White River and East Fork. Correlation of recharge basin topography and cave tiers is possible owing to the observation of 55 karst springs confined to lithostratigraphic contacts at three spring stratigraphic levels. Karst Spring Cutoffs are a specific type of vadose canyon diverting cave streams, bypassing around springs and passing into the laterally offset cave streams in the next lower cave tier. Cutoffs connect upper to middle tier cave streams and middle to lower tier cave streams as they enlarge below sinking stream basins and tributary spurs. Three speleogenic enlargement cycles characterize the eastern Leonard Springs Area, but only two cycles have enlarged in the western Garrison Chapel Area.
\end{abstract}

\section{Introduction}

Engineering projects use geotechnical borings in support of design and construction. This is not sufficient for karst regions where environmental and hydrogeological studies are necessary both before design phase and ongoing during construction phase. Dye tracing is a primary method to gain information about cave stream flow patterns and linking between multiple cave systems as it pertains to structural concerns and identifying base level decline surfaces.

Several local base levels may be present for a study area and it is necessary to identify the one that is relevant to a concern, and may be determined in part by examining the speleogenesis, rock unit lithology, and spring stratigraphic levels. Base level flow at a spring often becomes groundwater recharge through fissures channel underflow draining to the next lower base level spring in a region. Recharge is passed between multiple cave levels or cave tiers by karst spring cutoffs. Karst spring cutoff is a new term to describe a specific type of cave stream diversion associated with springs and linking between two cave tiers. A more detailed description and illustrated example follows in this paper.

Fluvial base level decline, lithology, and water chemistry are the primary agents controlling speleogenic enlargement of a vadose cave stream after speleogenic breakthrough. This study demonstrates a geologic description of a karst region by using the framework of stratigraphy and the cycle of speleo enlargement after breakthrough. The shallow karst spring cutoffs and the analog deeper vadose canyons are useful for identifying the cave stream linking across multiple cave tiers and have a geomorphic significance as points preserved from a former base level surface. The spring that was cutoff originated at grade with a former base level surface. The cutoff passage drains to a spring that enlarged at grade with a younger base level surface.

The topographic surface correlates with the present fluvial base level decline surface. Former base level decline surfaces are difficult to map because they are unconformable surfaces caused by differential erosion. This study projects an extended base level surface from a spring channel across a ridge with sinking stream basins where groundwater infiltrates into the karst aquifer, and across to the next spring channel.

\section{Methods}

This study is based on lithology and on detailed stratigraphy, measured rock unit profiles, and observation that many of the carbonate units are not entirely isotropic, but are very consistent in their matrix properties, joint patterns, and intensity of fractures over sufficient distances where a trunk cave stream enlarged in a lithostratigraphic interval. Trunk cave streams on cave maps were color indexed by rock units. The observation that 55 springs in the $80 \mathrm{~m}$ thick carbonate sequence are confined at speleogenic breakthrough to three discrete spring stratigraphic horizons provides the framework for delineating three cave tiers. Each trunk cave stream and 
spring can be fitted into a cave tier and allows the observation of multiple cycles of speleogenic enlargement in a tier across a watershed.

\section{Concepts}

The cave stream linking involves diversions beyond the general hydro-geometry characteristics described by White and Deike (1989). Karst spring cutoffs at Kirby Watershed are associated with full flow springs and represent a different aspect of cave tier linking beyond the elementary classification of overflow and underflow spring diversions described by Worthington (1991), and karst spring cutoffs are a different phenomenon in addition to the limited basin underflow described by Ray (1997).

The terms cave level and cave tier are generally synononyms, but more precisely level applies to hydrologic interpretation and tier has a stratigraphic connotation. The speleogenic states of inception and enlargement were described in the context of piezometric limits or cave levels by Palmer $(1987,2003)$ and for cave tiers by White (1988). One or more inception horizons may enlarge within the presently defined cave tiers, as inception horizons were defined by Lowe (1992).

Cave levels and cave tiers are often described as stacked vertically and having local diversions out of and back into trunk cave streams. At Kirby cave tiers are stacked vertically, but additionally have a laterally offset cave stream link between tiers where a karst spring cutoff diverts from a position upstream from the spring and passes below a narrow upper slope tributary or below the width of a larger sinking stream basin. This overview of Kirby Watershed is supported by an atlas of individual cave descriptions and a developing karst geology database for south-central Indiana.

\section{Location}

The Kirby Watershed includes a $42 \mathrm{~km}^{2}$ area of karst drainage severed from the former headland of Indian Creek located in south-central Indiana (Figure 1). Kirby Watershed is centered about the unincorporated village of Kirby at the intersection of Airport Road and Kirby Road: Latitude 39.14 degrees North, Longitude 86.61 degrees West; WGS 1984.

Kirby Watershed is underdrained by more than $34 \mathrm{~km}$ of mapped cave passages in three stratigraphically defined cave tiers and 55 springs confined at speleogenic breaththrough to three spring stratigraphic levels. The watershed is divided into the Leonard Springs and Garrison Chapel structural areas including a pattern of eleven karst valleys with perimeters bounded by topo-

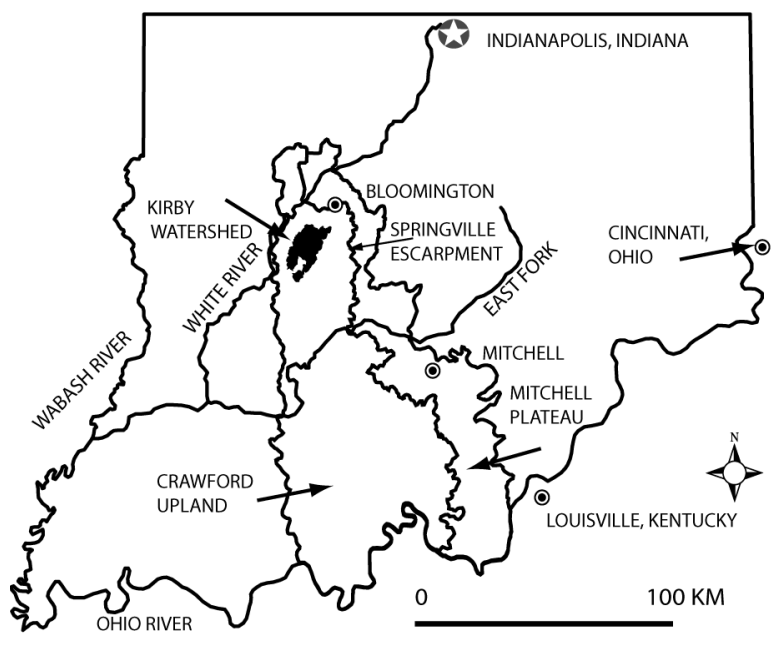

Figure 1. Kirby Watershed in south-central Indiana location map.

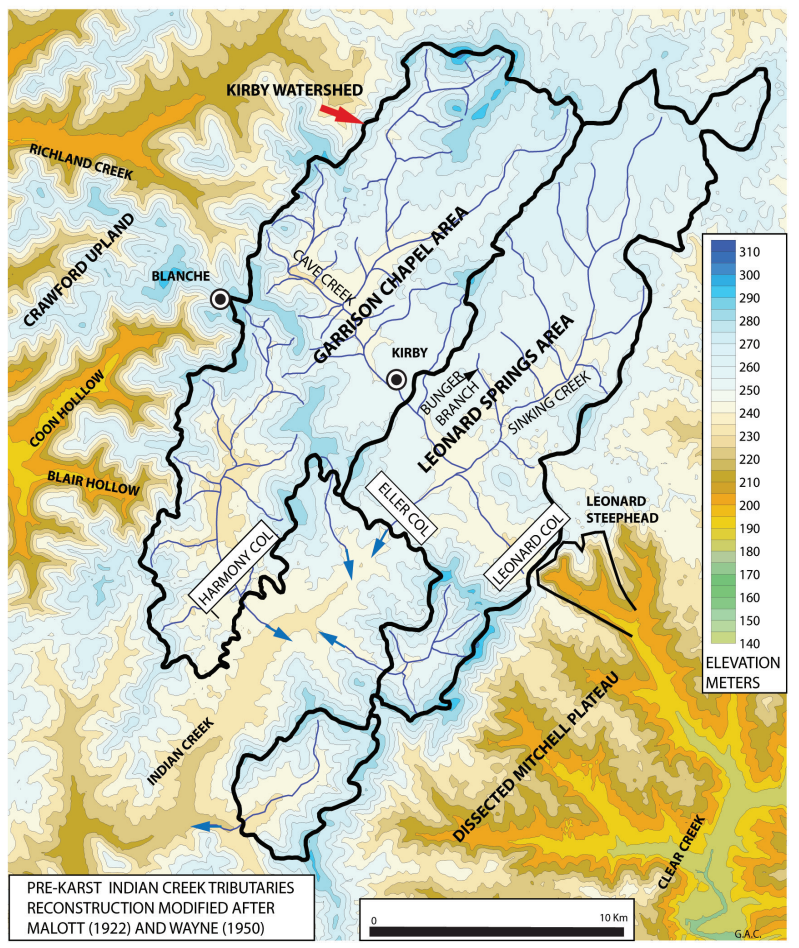

Figure 2. Kirby Watershed Topography based on U.S.G.S. NED Dataset, Physiographic Features, and PreKarst Tributary Reconstruction. 
graphic ridges and cols (Figure 2). The reconstructed branches of prekarst and early karst tributaries to Indian Creek are identified for Kirby Watershed (Figure 2). Each karst valley evolved around a pre-karst tributary branch that was later modified to the shape of one or more internal sinking stream basins and underdrained by the successive cave tiers (Figure 3).

\section{Earlier works}

The name Kirby Watershed is applied to the former headland branch of Indian Creek with subterranean stream piracy and karst geology described by Beede (1911). Malott (1922) illustrated thirty-six ponors (swallets) and nine storm water rises (springs) in Kirby Watershed on a township map with reconstruction of the pre-karst drainage channels. The western portion of the watershed near the village of Blanche includes a karst valley with pre-karst drainage illustrated by Wayne (1950). Powell (1965) described karst hydrology for four westward flowing cave streams near Blanche. DesMarais (1973) compiled cave maps and descriptions of caves in the area now described as Kirby Watershed. DesMarais (1981) used mercaptan air tracings to identify four cave streams and flow abandoned upper levels in the western portion of the former headland of Indian Creek referred

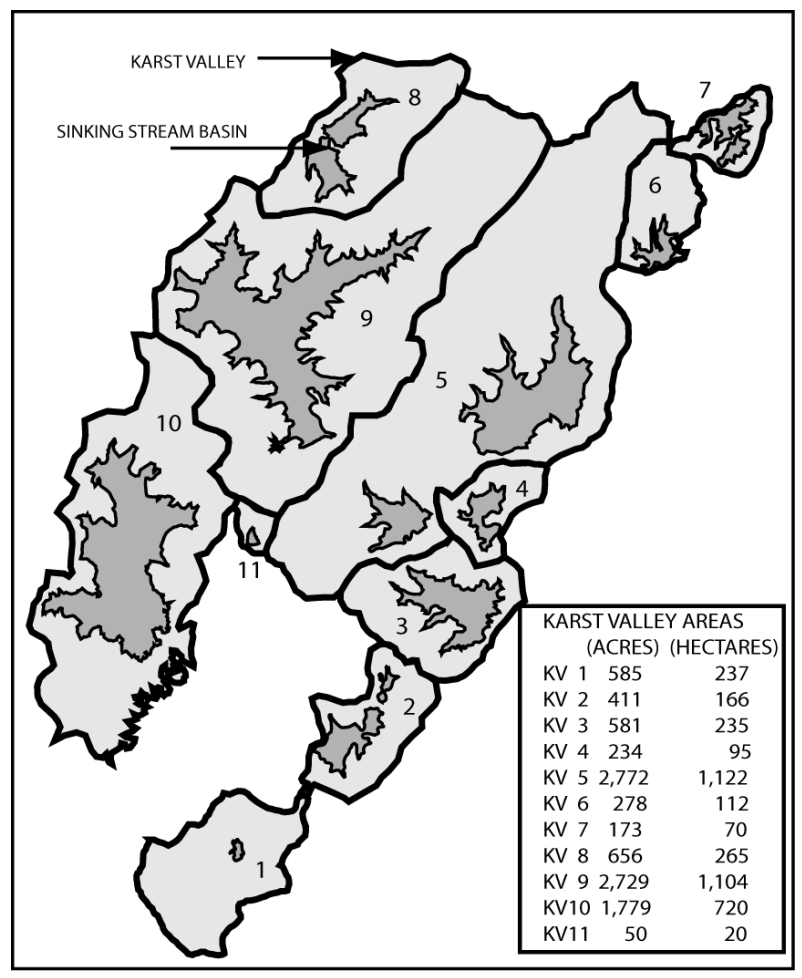

Figure 3. Kirby Watershed former headland of Indian Creek, 11 karst valleys and interior sinking stream basins. to as the Garrison Chapel Area (1981) (Figure 2). Reconaissance stratigraphy in the region was developed by Malott (1952). Precision cave stratigraphy was mapped by Conner (1987).

\section{Rock Units}

The Mississippian Period Blue River Group averages 80 $\mathrm{m}$ in thickness and comprises a major karst forming unit in south-central Indiana, western Kentucky, and southern Illinois. The upper half includes multiple and truncated shoaling oolite cycles. The lower half of the group includes dominantly organic stained micrite, pellet, and dolomicrite beds with intercalated sparite and coarsely crystalline biocalcarenite beds. The shoaling cycle starts with pelletal muds, is followed by calcarenites and oo-

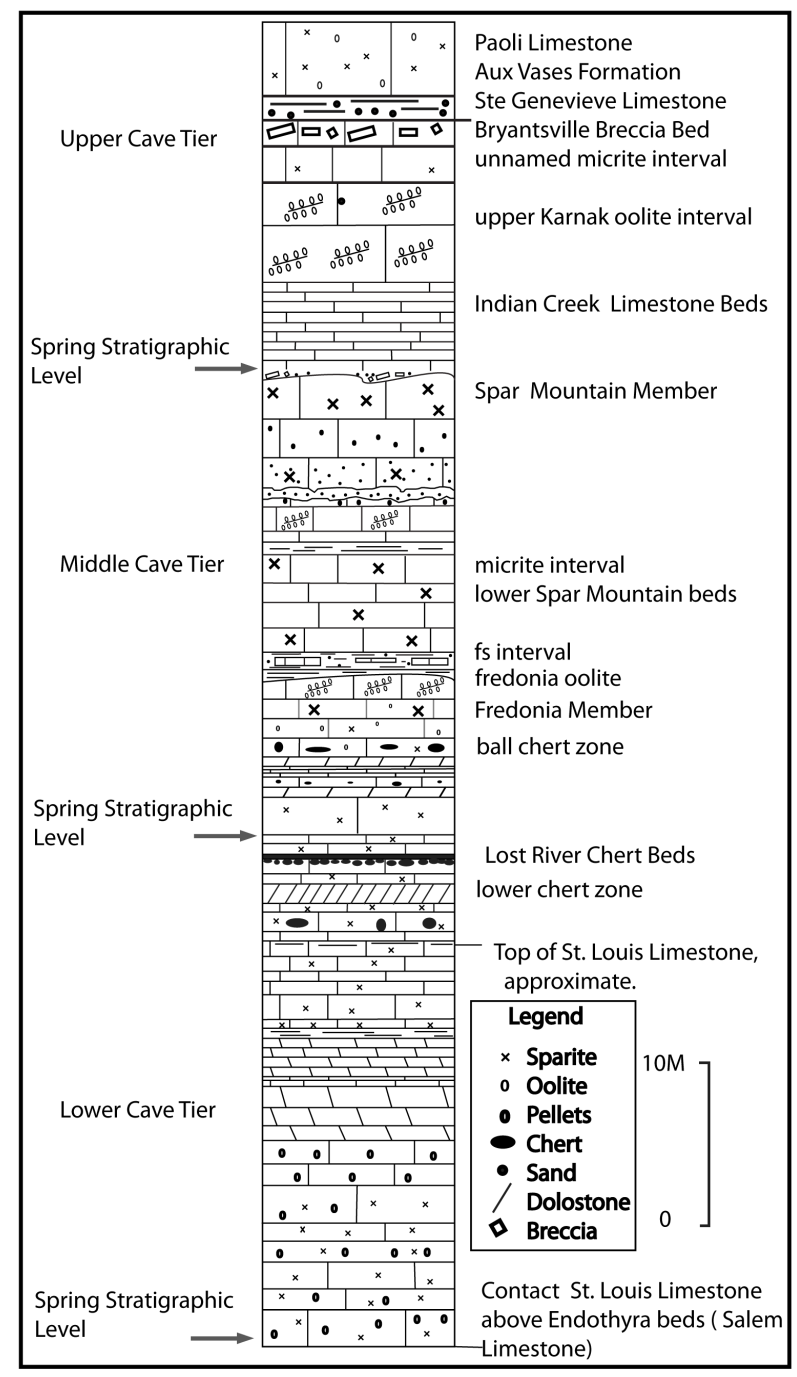

Figure 4. Geologic Column for Mitchell Aquifer and Kirby Watershed, upper case named units, lower case informal units. 
lites, and is capped by a thin shaley or sandy limestone. The pelletal mud interval observed throughout caves and core holes in south-central Indiana is populated by a high purity lithographic textured micrite which is very brittle, has closely spaced conchoidal fractures, and reveals a ductility contrast to the interbedded oolitic calcarenites. The micrite is often thinly bedded, 5 to $7 \mathrm{~cm}$, in a $5 \mathrm{~m}$ interval. The oolitic calcarenite beds are massive up to 7 $\mathrm{m}$ thickness. Mississippian carbonates in the Kirby Watershed are shown on the geologic column (Figure 4).

\section{Mitchell Aquifer}

The Mitchell Aquifer is introduced as a hydrostratigraphic unit concurrently with description of three cave tiers and karst hydrology in the Mississippian Period Blue River Group in south-central Indiana. The name Mitchell is given as a geographic reference to the city in nearby Lawrence County, Indiana. The name Mitchell was also used in the stratigraphic name Mitchell Limestone with its original interval expanded and later modified, as it was reviewed by Smith (1986) and was replaced by the Blue River Group named by Gray et al. (1960). Karst conduits, springs, and cave streams in the Mitchell Aquifer extend across a ten county area in the Crawford Upland and Mitchell Plateau in south-central Indiana $\left(110,000 \mathrm{~km}^{2}\right)$.

\section{Physiography}

Kirby Watershed with sinking stream basins evolved athwart a headland mass of the Crawford Upland dividing the drainage between White River and East Fork. Local relief for the Crawford Upland is $90 \mathrm{~m}$ and for the Mitchell Plateau is $60 \mathrm{~m}$ north of East Fork River. The transitional boundary between the upland and plateau is characterized by the Springville Escarpment (Gray, 2000).

\section{Bedrock Structure and Flow Zones}

Measured rock unit profiles in the caves were used to map a structural datum on top of the Indian Creek Limestone Beds for comparison to the surveyed cave stream altitude trends (Conner, 1986). An apparent dip of $7 \mathrm{~m} /$ $\mathrm{km}$ to the southwest is interpreted from the structure contours (Figure 5).

Upper to middle cave tier links through karst spring cutoffs are shown by color indexed lines and illustrate reversal of flow direction or deflections of up to 60 degrees in plan view. Some lower tier cave streams drain down stratigraphic section, but up the structural bedrock slope. This occurs in a thick well jointed micrite interval where thin weathered beds are exposed at Leonard Steephead. Flow direction changes or reversals related to cave tier links are illustrated (Figure 5). Dye tracings are from
Conner (1973) DesMarais (1981) Krothe (2003) and Frushour (2006) as used in (Figure 5).

Reeves and Goodes Cave system was level tube surveyed for comparison of passage ceilings and thalwag gradients to true bedrock dip. This system is enlarged in an anticlinal structure plunging $11 \mathrm{~m} / \mathrm{km}$ southwest. Visual estimates of structure were made for other caves using apparent dip and rock unit thicknesses. Cave streams at Kirby flow down the bedrock slope in the upper and middle cave tiers with three distinct flow zones typically recognized by thalweg gradients within both tiers. The fissures and swallets zone is relatively steeper. The gradient through the inception horizon zone follows the dip or is slightly steeper. And the karst spring cutoffs zone is oriented down the dip with thalwegs graded between 12 and $21 \mathrm{~m} / \mathrm{km}$. Some cascades ranging $5 \mathrm{~cm}$ to $3 \mathrm{~m}$ in depth factor into the thalweg steepness. Graded flow zones are illustrated in (Figure 6). A detail to be noted is the karst spring cutoff zone at the top of the middle tier occurs in the same rock interval as the fissures and swallets zone for the middle tier. The difference is that the cutoff drains an upper tier cave and the fissures and swallets zone captures surface water as well.

\section{Spring Stratigraphic Levels}

Spring stratigraphic levels at Kirby are defined for a bedding plane parting on the base of a lithostratigraphic interval bearing evidence of the flow position at the time of speleogenic breakthrough. The definition is based on rock unit sections measured at springs where the level of initial flow is preserved and can be recognized, (Conner, 2011). The spring discharge point at the time of speleogenic breakthrough flows at the position of the spring stratigraphic level. After speleogenic enlargement commences the spring thalweg entrenches below the base of the inception horizon. Spring stratigraphic levels are shown (Figure 4).

\section{Cave Tiers}

The cave tiers are defined with their bases at a spring stratigraphic level and the upper bound is the next higher spring stratigraphic level in the carbonate sequence. The upper tier caves at Kirby generally have one cave level corresponding to one primary inception horizon, but the middle tier caves typically have multiple piezometric limits corresponding to transitions between multiple inception horizons within the cave tier. The spatial relation between cave streams, flow zones related to structure, and cave tiers is shown (Figure 6).

\section{Karst Spring Cutoffs}

Karst spring cutoffs are vadose canyons intercepting a cave stream above a spring and diverting it below, by- 


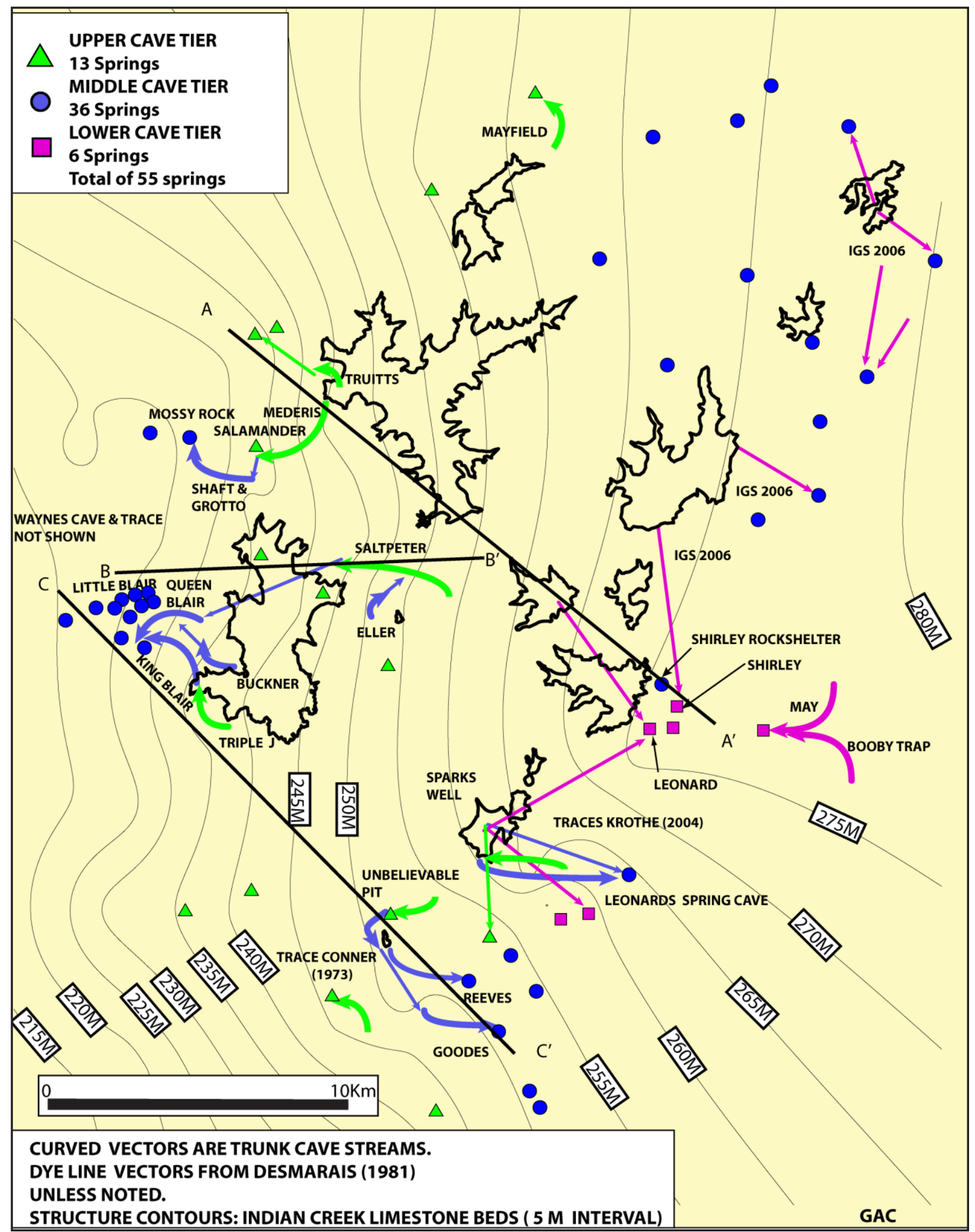

Figure 5. Cave Tiers, Springs, Dye Traces, and Structure Contours for Indian Creek Limestone Beds. 
passing the spring and linking with the next lower cave tier. This pattern also occurs for springs on the structurally high side of broad sinking stream basins where the intercepting cutoff canyon passes below the basin and drains down the bedrock slope through a fissures and swallets zone before draining into an inception horizon in the next lower cave tier.

Karst spring cutoffs are vadose canyons with a vertical rectangular outline and little upward enlargement above the initiating bedding plane. The cutoff ceiling declines downstream through successively lower bedding planes. The up-stream segment of the cutoff thalweg is much steeper than bedrock dip, cascading through thin beds, and becomes closer to horizontal or follows the bedrock slope through the downstream channel. The system of Salamander, Shaft, and Grotto caves illustrates a karst spring cutoff. The cutoff canyons below the tributaries and basins are analogs of canyons below high sandstone capped ridges and both canyon types cross-cut the contact between two cave tiers. A karst spring cutoff example is illustrated in (Figure 6).
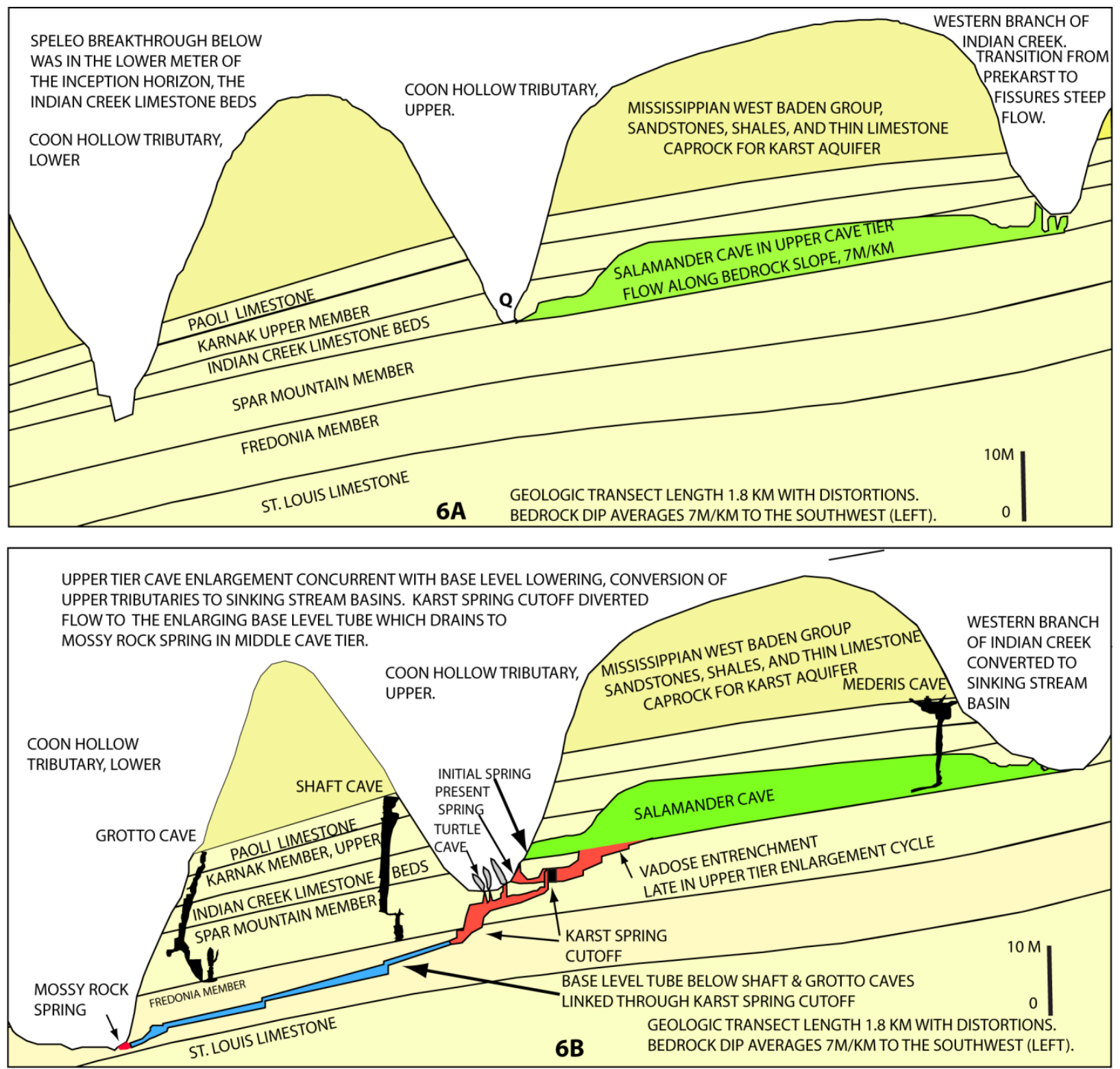

Figure 6. Coon Hollow Transects: Upper Cave Tier Enlargement (6A) and later in Middle Tier (6B) with linking through Karst Spring Cutoff. 


\section{Discussion}

A study combining base level decline and trunk cave streams related to a phase or cycle of speleogenic enlargement involves the initial spring discharge elevations at the time of breakthrough and afterward during the general period of enlargement. The segment of the trunk cave stream passing from some distance upstream from the spring and discharging out of the spring through a short reach of the spring channel is observed at Kirby to become entrenched with a thalweg steeper than the bedrock slope below the base of the inception horizon. The vadose cave stream and its sinking stream basin source above do not decline at the same rate.

Accurate reconstruction of former base level decline surfaces correlating with the enlargement phase for the three cave tiers is difficult. However, the karst spring cutoffs and the spring profiles provide points on the former base level surface that coincide generally with the present topographic surface; and provides useful information for environmental and geotechnical evaluations. Two images show the same transect, one with an approximation the pre-karst topographic surface, base level when the upper tier cave entered breakthrough phase (Figure 6A). The other shows the present topographic profile and relation to the features of a middle tier cave with a spring cutoff (Figure 6B).

The location for three transects of Kirby Watershed are shown (Figure 5). Transects show the present topographic surface and flowing trunk cave streams for the three cave tiers (Figure 7). Karst spring cutoffs identify points on former base level decline surfaces associated with enlargement in a cave tier.

The relation of an upper tier cave, Truitts Cave, and a lower tier cave, Shirley Springs cave is shown relative to the topographic surface. The transect (Figure 7A) shows the present topographic surface which has declined since the Truitt's Cave stream enlarged in the upper cave tier and has entrenched into the upper Spar Mountain Beds in the cave and at the spring, but no middle tier enlargement related to a middle tier spring has been observed. The same topographic surface extending to the east shows a recharge basin for active cave streams in both the middle and lower cave tiers. There is reasonable evidence that there was westward flowing upper tier cave enlargement potential above the present surface in the east if the westward flowing upper portion of Reeves Cave is considered, shown (Figure 7C). The upper portion of Reeves Cave enlarged flowing to the west, at grade with a former eastern branch of Indian Creek; since captured by the present sinking stream basin flowing to Goodes Branch of Clear Creek. Another example is the upper tier portion of Leonards Spring Cave shown in plan view (Figure 5). Shirley Rockshelter Cave is a relict passage after a spring that became flow abandoned and mud filled in the middle cave tier.

The transect (Figure 7B) shows Saltpeter Cave enlarged in the upper cave tier with a former spring draining into the western branch of Indian Creek. The former spring was diverted by a karst spring cutoff that drained toward a middle tier enlarging cave, Queen Blair. The diversion was contemporary with the early formation of the sinking stream basin in karst valley 10 . The active stream in Saltpeter Cave has entrenched with a thalweg into the Spar Mountain Member, but there is no known deeper cave enlargement in the lower tier below the mapped Saltpeter Cave.

The transect (Figure 7C) at the downstream end of Kirby Watershed shows an example of an active middle tier cave stream draining to Richland Creek to the west and an upper and middle cave tier example to the east draining toward Clear Creek. The stream in Reeves Cave upper segment remains active after the spring was abandoned for a karst spring cutoff which appears not to have passed through the main stream in Reeves Cave, but drained through Goodes Cave. Both Reeves and Goodes trunk cave streams are in the middle cave tier.

\section{Conclusion}

Identifying spring stratigraphic levels, delineating lithostratigraphic cave tiers, and correlating cave streams with present and former base level decline surfaces is a method of investigating karst flowpaths and their relation to speleogenic enlargement. Flow zones described in this paper and their gradients in addition to the bedrock slope orientation of flowpaths in a cave tier are helpful for interpreting gradients between piezometric limits. The concept is extensible to other areas of the Mississippi Valley Plateaus region for gently dipping and relatively unfaulted limestone strata. Identifying the structure oriented flow zones related to a cave tier improves understanding of flow patterns and changes in an area as base level declines. The changes in flow direction are associated with the headward expansion of a karst plateau and capture of groundwater from an eroding upland at Kirby Watershed and along the Springville Escarpment.

\section{Acknowledgements}

The author wishes to acknowledge the long term successes of Keith Dunlap in establishing the Indiana Karst Conservancy, Sam Frushour of the Indiana Geological Survey for efforts supporting the Richard Blenz Nature Conservancy and the Blooming- 

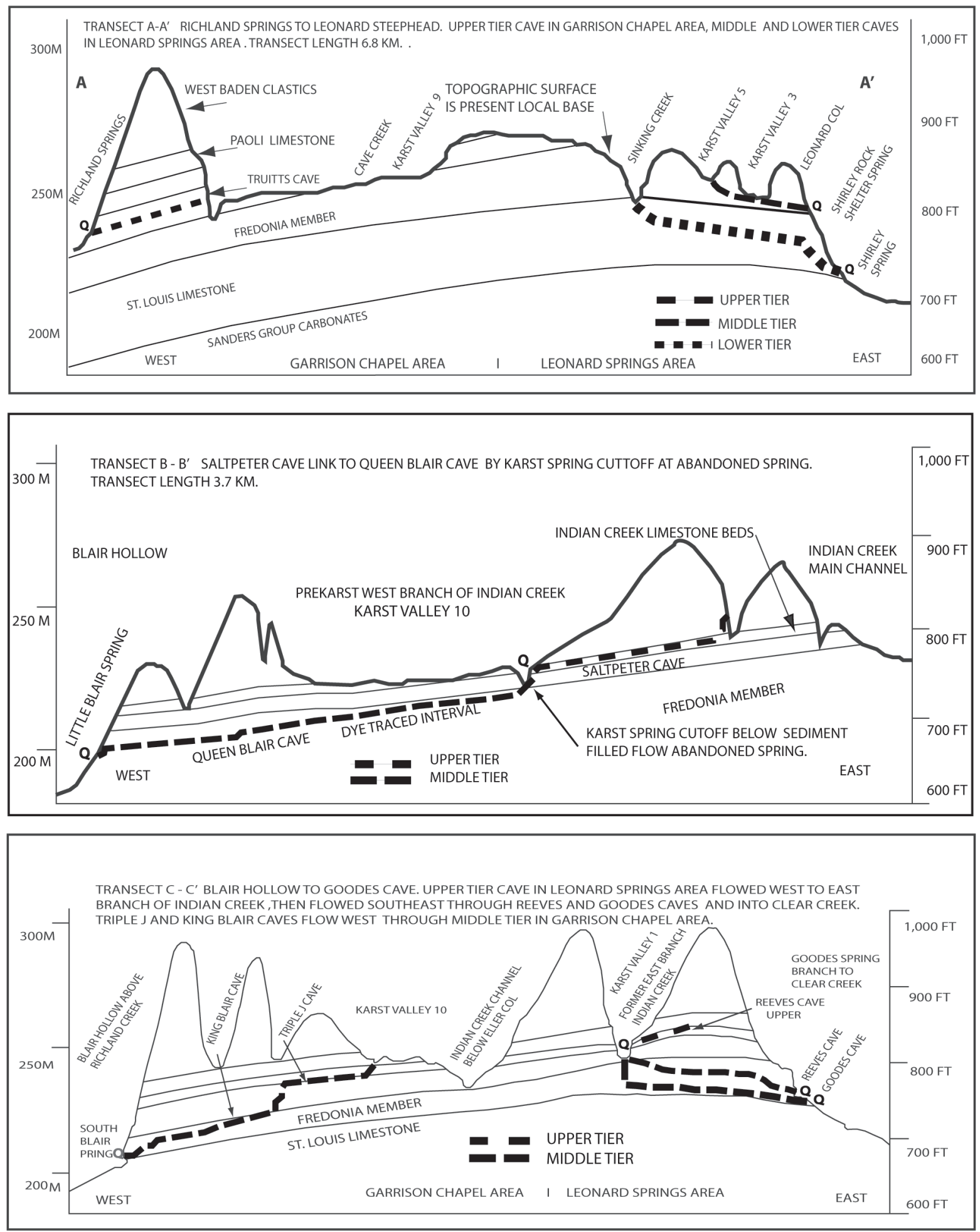

Figure 7. Hydrogeologic Transects with Trunk Cave Streams in Cave Tiers and Karst Spring Cutoffs correlating to Base Level Decline Surfaces. 
ton Parks Department for establishing the Leonard Springs Nature Park. Their dedicated stewardship to the karst and cave resources in Kirby Watershed and other areas in southern Indiana is greatly appreciated.

\section{References}

Beede JW. 1911. The cycle of subterranean drainage as illustrated in the Bloomington, Indiana Quadrangle. In: Proceedings for the Indiana Academy of Science for 1910 20: 81-111.

Conner GA. 1973. Dye trace in Reeves Cave, unpublished notes.

Conner GA. 1986. Type section for Indian Creek Beds in the Ste. Genevieve Formation of South-Central Indiana. In: Proceedings, Indiana Academy of Science for 1985 95: 307-311.

Conner GA. 1987. Stratigraphic sections in the Ste. Genevieve Formation (Middle Mississippian) exposed in Garrison Chapel karst area caverns Western Monroe County, International Journal of Speleology 16: 79-94.

Conner GA. 2011. Limestone cavern rock-unit profiles for the Mississippian age Blue River Group in Leonard Springs Area of southern Indiana. In: Proceedings, Indiana Academy of Science for 2010 119 (2): 174-179.

DesMarais DJ. 1973. The Garrison Chapel Karst Area. In: DesMarais DJ, Spaulding G, Wilson W, and Moore M, editors. National Speleological Society Guidebook [for the National Speleological Society Convention in Bloomington, June 16-24, 1973]. National Speleological Society. Huntsville.

DesMarais DJ. 1981. Subterranean stream piracy in the Garrison Chapel Karst Valley, Indiana USA. In: Proceedings, International Congress of Speleology, 8th Meeting, Bowling Green I, II: 196-199. International Union of Speleology. Americus, Georgia. USA.

Frushour SS. Harper D. Dintaman C. 2006. Karst Dye_Pts_IN.SHP and Karst_Dye_Lines_IN.SHP. In: Miscellaneous Map series (MM66). Selected subsurface dye traces in South-Central Indiana. Indiana Geological Survey. Bloomington.

Gray HH., Jenkins RD, Weidman RM.1960. Geology of the Huron area, South-Central Indiana. Indiana Geological Survey Bulletin 20: 78.

Gray HH. 2000. Physiographic Divisions of Indiana: Indiana Geological Survey Special Report 61.

Krothe NC. 2003. Results of the Spark's Farm dye tracing test. Report filed with Monroe County Planning Commission. Bloomington, Indiana.

Lowe DJ. 1992. The origin of limestone caverns: an inception horizon hypothesis. [PhD thesis] Manchester Polytechnic. p. 512.
Malott CA. 1922. The physiography of Indiana. In: Logan WN., editor. Handbook of Indiana Geology, Indiana Department of Conservation 21 (2): 59256.

Malott CA. 1952. Stratigraphy of the Ste. Genevieve and Chester Formations of Southern Indiana: Edwards Letter Shop. Ann Arbor, Michigan, p. 105.

Palmer AN. 1987. Cave levels and their interpretation: National Speleological Society Bulletin 49: 50-66.

Palmer AN. 2003. Speleogenesis in carbonate rocks. In: Gabrovsek F. Editor. Evolution of karst from prekarst to cessation. Postojna-Ljubljana, Zalozba ZRC, 43-60.

Powell RL. 1965. Development of a karst valley in western Monroe County, Indiana (abstract). In: . Proceedings for the Indiana Academy of Science 1964 74: 222.

Ray JA. 1997. Overflow conduit systems in Kentucky: A consequence of limited underflow capacity. In: Beck B., editor. The Engineering Geology and Hydrogeology of Karst Terranes. Balkema, Rotterdam.

Smith NM. 1986. Mitchell Limestone. In: Shaver RH, Ault CH., Burger AM., Carr DD., Droste JB., Eggert DL., Gray HH., Harper D., Hassenmueller NR., Hassenmueller WA., Horrowitz AS., Hutchinson HC., Keith BD., Keller SJ., Patton JB., Rexroad CB., Weir CE., editors. Compendium of Rock Units in Indiana: Indiana Geological Survey Bulletin 59: p. 203.

Wayne WJ. 1950 A karst valley in western Monroe County, Indiana (abstract) In Proceedings: Indiana Academy of Science for 1949 59: p. 258.

White WB. 1988. Geomorphology and hydrology of karst terrains. Oxford University Press. p. 464.

White WB, Deike III GH. 1989. Hydraulic Geometry of Cave Passages. In: Karst Hydrology Concepts from the Mammoth Cave Area. White WB. White EL. Editors. The Pennsylvania State University. Van Nostrand Reinhold New York p 223-258.

Worthington, SRH. 1991. Karst hydrology of the Canadian Rocky Mountains. [PhD thesis]. McMaster University: p. 237.

14TH SINKHOLE CONFERENCE NCKRI SYMPOSIUM 5 
